\title{
Welfare reform, precarity and the re-commodification of labour
}

\author{
Ian Greer, University of Greenwich \\ i.greer@greenwich.ac.uk
}

Accepted by Work, Employment, and Society, January 2015

While welfare reform matters for workers and workplaces, it is peripheral in Englishlanguage sociology of work and industrial relations research. ${ }^{1}$ This article's core proposition is that active labour market policies (ALMPs) are altering the institutional constitution of the labour market by intensifying market discipline within the workforce. This recommodification effect is specified drawing on Marxism, comparative institutionalism, German-language sociology, and English-language social policy analysis. Because of administrative failures and employer discrimination, however, ALMPs may worsen precarity without achieving the stated goal of increasing labour-market participation.

Keywords: workfare, active labour market policies, precarity, precariat, industrial reserve army, labour re-commodification, welfare reform, labour markets.

\footnotetext{
${ }^{1}$ For helpful comments, many thanks to Matthias Knuth, Rob MacKenzie, Sarah Nies, Peter Streckeisen, Ozlem Onaran, Mark Stuart, Matt Vidal, and three anonymous reviewers, as well as the participants of the stream "Jobs and Joblessness in the Crisis" at the International Labour Process Conference, 5-7 April 2011, in Leeds.
} 
There is nothing counter-intuitive or new about the claim that work and employment are shaped by welfare states and experiences of unemployment. Welfare reformers in the UK, for example, have long seen welfare state reform as a way to stimulate labour market activity, by putting downward pressure on wages (Nickell 1997) or reducing barriers to labour market entry (Levitas 1998). While the classics of industrial relations and the sociology of work discuss this connection (Webb and Webb 1905; Braverman 1975), welfare reform has only been examined on the margins of these fields.

Numerous studies of labour market exclusion and marginality have appeared in Work Employment and Society (e.g. Fevre 2011). They show that redundant manufacturing workers, lone parents, the disabled, young unemployed people and members of other marginalized groups each have specific and complex needs; and that the expansion of any of these groups leads to escalating demands on public policy (Rubery 2011). However, they also provide evidence of policy failing to meet these needs in the context of hazardous life transitions such as redundancy (Weller 2010) or school leaving (Furlong 2006). Why is the public policy response to unemployment so often ineffective?

This article starts with the observation that welfare reforms have, over the past few decades, taken the form of Active Labour Market Policies (ALMPs), which have aimed to increase labour market participation and reduce spending on jobless benefits. The core argument is that, in doing so, ALMPs tend to alter the institutional regulation of the labour market by re-commodifying labour. This article specifies ALMPs and their effects in light of the spread of workfarist social policy and a contrast between the industrial reserve army mechanism and precarity. It then spells out the re-commodification effect and the 
administrative failures, employer discrimination and claimants' resistance that shape it. This article concludes that, whatever the effectiveness of ALMPs in terms of increasing labour market participation, their likely effect will be intensified labour market discipline.

\section{Workfarist social policy}

Activation as a policy concept emerged in response to criticisms of welfare states, starting shortly after most assumed their modern forms in the 1960s and 1970s. Welfare benefits were thought to reduce workers' incentives to take jobs, incur costs that reduced capitalists' incentives to invest, and reinforce long-term unemployment and associated inequalities of income, wealth, health and happiness. Slogans such as 'no rights without responsibilities' and 'any job is better than no job' gained currency among mainstream academics and policymakers. Welfare states, however, could not be abolished due to the role they played in maintaining order and the vested interests they engendered in democratic polities (Offe 1984; Pierson 1994). Jessop (2002) argued presciently that the resulting reforms would subordinate social policy to the needs of employers, although the exact policy mix was unpredictable and with different conceptual models of ALMP competing in the policy discourse.

One model, 'flexicurity', was inspired by Danish and Dutch examples and promoted by the European Commission; it also attracted interest from industrial relations scholars (e.g. Gray 2004; Heyes 2011; Johnston et al 2013). Flexicurity advocates argued that competitiveness in world markets required flexible labor markets, including weak statutory employment protection and requirements that welfare claimants look for work. However, they also argued that strong social rights and protection were necessary to support worker transitions between jobs, including income protection and vocational training. The reconciliation of flexibility and security would work best, it was argued, if they were 
underpinned by cooperation between strong unions and employers associations (Auer 2010). The consequences would resemble Pontusson's (2012) depiction of labour markets under social democratic welfare states: 'to bring people into the labour market and empower them as sellers of labour power' (p. 98).

A second model of ALMP, 'workfare', emerged from welfare reforms in the United States, most notably through the so-called Personal Responsibility and Work Opportunity Reconciliation Act of 1996. PRWORA reformed welfare benefits for low-income families a disproportionate number of which were claimed by non-white lone parents - by introducing work requirements, a five-year time limit, greater local discretion in implementation and new restrictions on immigrants' eligibility (Blank 2002). Workfare, however, took on a broader meaning beyond any one policy and became a catch-all term for any form of labour activation aimed at re-regulating the labour market through an emphasis on job search (rather than training), conditionality and sanctions (rather than unconditional entitlements) and a 'flexible' organizational structure of service delivery involving contractors, market mechanisms and orientation toward local employers (Peck 2001).

The notion of workfare should have fired the imagination of labour process and industrial relations theorists, since it pointed to institutional changes intended to intensify control over job seekers and make them more compliant in low-wage jobs. California's GAIN programme of the 1980s and 1990s, for example, was assessed positively in evaluation research, both in terms of increasing clients' earnings and in terms of reducing benefit payments (Greenberg et al 2005). GAIN downplayed skills training and emphasized quick placements in private-sector jobs; the latter was underpinned by a programme to alter the attitudes, behaviour and self-image of welfare claimants, through an upbeat message of empowerment, a set of rules (on-time attendance, daily job search, no food, drink, or chewing 
gum and a dress code) and steep financial penalties for non-compliance. Employment counsellors monitored attendees and were required to achieve ever-increasing job placement outcomes (Peck 2001: 168-210). GAIN performed unusually well and influenced the subsequent rollout of welfare programmes across the US from the late 1990s, even though its advocates admitted that its 'success' may have been due to the rapid expansion of servicesector work in a particular local labour market rather than the characteristics of the programme (Greenberg et al 2005).

The comparative literature shows that while workfarism diffused across the English and German-speaking countries (Peck 2001; Scherschel et al 2012), attempts to diffuse the alternative beyond the 'flexicurity countries' (the Nordic countries and the Netherlands) were hampered by the scepticism of policymakers and social partners (Auer 2010). There were areas of convergence, such as the extension of job-search requirements to inactive groups (Eichhorst and Konle-Seidl 2008), but not in terms of increasing security through increased spending on vocational training or welfare benefits (Heyes 2011; Clasen and Clegg 2013). While there is no comparative dataset that captures the pressures placed on claimants by these reforms, the consensus in this literature is that rolling back worker protection has not been countered by spending to increase worker security (see above sources and Gray 2003).

ALMPs thus have workfarist tendencies in countries known for differing social 'models'.

\section{Re-commodification and the reserve army mechanism}

One result of this change in welfare states is escalating pressure on workers and unemployed people. During their phase of expansion, welfare states produced, to varying degrees, the 'decommodification' of labour by intervening in labour markets in a way that loosened the discipline of the labour market (Esping-Andersen 1990). Since welfare reformers attempted 
to reverse this effect and reinstate labour market discipline, the term 're-commodification' came into use (Offe 1984). In line with that tradition, the definition of re-commodification proposed here is any institutional change that reinstates the discipline of labour market competition on workers, whether in or out of work, and whether through reforms to welfare states, industrial relations, or labour markets. In contrast to that tradition, however, recommodification is not defined here purely in terms of the opposite of de-commodification; instead it entails new forms of administrative control over workers and job-seekers. Welfare states are not the only source of re-commodification (the loosening of other labour market rules and new management techniques in the workplace could also have this effect); and unemployed welfare claimants are not the only people whose labour could be recommodified (job holders can be affected through changes to in-work benefits). But welfare reform is an important lever for intensified labour market competition, especially in the lowwage and insecure segment.

The reserve army mechanism is central to the Marxist theory of unemployment and the labour market. Marx himself defined the industrial reserve army as a 'relative surplus population' generated by and needed by capitalism, whose standard of living is below that of the working class, and whose members are available for exploitation in expanding areas of the economy. He divided it into three groups: 'floating' (workers made redundant due to economic downturn or greater efficiency), 'latent' (migrants from agricultural areas) and 'stagnant' (paupers and vagabonds). In times of economic crisis or technological change, employers make large numbers of workers redundant, thus renewing the reserve army. The function of the reserve army is to keep down the cost of labour in new and expanding industries, even at times of overall growth and increasing employer demand (Marx and Engels 1973: 640-740). 
The reserve army mechanism remained in the Marxist analytical toolkit during the 1970s and 1980s. Braverman (1975), for example, applied Marx's schema to workers made redundant by automation and other forms of industry restructuring (floating), who move from job to job supported by unemployment insurance; immigrants and 'housewives' moving into the formal labour market for the first time (latent); and others, including 'discouraged workers' outside of unemployment statistics, who may receive social assistance while working in casual jobs (stagnant). Sociologists also applied the concept, for example, to the exploitation of women entering the workforce for the first time as low-wage flexible workers (Collinson 1987). More recently social policy analysts have used it to examine the UK Government's labour market policies (Grover 2005; Wiggan 2014).

Nevertheless, the significance of the reserve army changed with the build-up of the welfare state. Green's (1991) review of the Marxist economics literature of this period finds the reserve army mechanism undermined by welfare states, which alleviated the 'distress' of unemployment that might otherwise have led to lower wages and intensified management control. Significant numbers of jobless people were taken out of the reserve army by welfare states, because they were no longer available for work in a way that might produce these kinds of short-run labour market effects across the economy. Similarly, new entrants to the labour market such as women and migrants faced systematic exclusion from much of the labour market due to segmentation processes. Green correctly argues that these groups cannot be considered part of the reserve army if they are not carrying out work under poorer terms and conditions than the rest of the workforce, and if their members are prevented from replacing other workers.

Comparative institutionalist social science treated these effects of the welfare state as the 'decommodification' of labour, drawing on Polanyi's (1957) account of the re-constitution 
of labour as a 'false commodity'. Polanyi's historical reference point was the 1834 repeal of England's Speenhamland poor relief arrangements. Over the decades that followed, Polanyi argued, the free functioning of labour markets was undermined by society's responses to their undesirable effects; he uses this lens to explain the rise of factory laws, unemployment insurance and trade unionism. Esping-Andersen (1990) extended this idea to a broader conception of decommodification through pension systems, unemployment insurance and social assistance arrangements in the $20^{\text {th }}$ century. In countries with high decommodification, he argued, the welfare state would strengthen workers' bargaining power as they moved between jobs (through the unemployment insurance system) and allow some of the non-working population to stay out of the reserve army (through pension and disability benefits and poor relief). In Marxist terms, welfare states re-shaped labour markets by interfering in various ways with the reserve army mechanism.

What happens when welfare reforms take place to reinstate labour market discipline? Mandatory participation in activation programmes and punishments for non-participation increase the loss of income, and hence the distress, associated with unemployment. These pressures are extended beyond the 'unemployed' (jobless workers in the unemployment insurance system) to young people in school-to-work transitions and parts of the 'inactive' population (e.g. the disabled and lone parents). Any remaining comforts of unemployment are reduced by the actions of advisers (e.g. pressure to accept job offers) and changes in benefits and tax credits (e.g. 'incentives'). The stated aim of ALMPs is to increase the number of available job seekers, encourage wage moderation and increase labour flexibility. The Jobs Study of the Organization for Economic Development and Cooperation (OECD), for example, suggested that 'active measures may lead to wage moderation by strengthening the ability of 'outsiders', particularly the long-term unemployed and first-time job-seekers, to 
compete more effectively for jobs' (1994: 36). Documents like this come close to embedding the recognition of capital's need for an industrial reserve army within social policy, even if combined with other goals and discourses (e.g. Levitas 1998) and in countries such as Germany that supposedly accept core principles of the International Labour Organization such as 'labour is not a commodity' (Declaration of Philadelphia, 1944).

Intentions and effects, however, are two different things. The rollback of the welfare state is not just the reverse of its build-up (Pierson 1994), and efforts to activate the reserve army mechanism are not generally successful. The rest of this article makes the case that the failure of these policies to achieve their stated objectives does not necessarily prevent recommodification effects.

\section{Discipline and precarity}

The literature on precarity is the terrain on which re-commodification has to be understood, since the 'precariat' is the group most vulnerable to welfare reforms. It faces, by definition, chronic job and income insecurity, weak welfare entitlements, and a back-and-forth motion between employment and unemployment statuses; consequently, itis more exposed to ALMP schemes than other workers. Recent English-language debates have taken place over whether there is a 'precariat' with special characteristics and the spread of 'precarity' - i.e. perceived insecurity and deteriorating job quality - across the quasi-permanent workforce (Doogan 2009; Standing 2011; Kretsos and Livanos 2013; review symposium on Standing's book in WES issue 26:4). The present analysis moves beyond the terms of this debate. While the market discipline of ALMPs exacerbates both the vulnerability of the precariat and the insecurity of quasi-permanent workers, the two groups and their experiences of precarity are not equivalent, especially when it comes to their experiences with the welfare state. 
Robert Castel (2003, first published in French in 1995) provides an important starting point for the present analysis and the French- and German-language sociological treatments of precarity. Drawing on Durkheim, he argues that, starting in the late 19th century, wage labour across Western Europe changed from an engine of mass vulnerability to one of social integration, as a group of job-holders formed with quasi-permanent jobs, collective agreements and social insurance benefits. Against the historical backdrop of wage labour giving rise to this 'zone of integration', he defines two additional groups, also in terms of work and non-work statuses: vulnerability (dealt with by German sociologists as a precariat moving back and forth between these statuses, while failing to achieve anything like social integration through work [Brinkmann et al 2006]) and disaffiliation (known more statically in policy discourse as social exclusion, which involves remaining outside the world of wage labour). The zone of vulnerability captures a transitional state between work and non-work and is shaped by the institutions that regulate transitions between the two. Castel argues that welfare administration shapes the vulnerable population through its 'handicapology', which he defines as the classification of individuals in terms of barriers to paid work. Job seekers are defined in terms of these barriers, he argues, and activation becomes a 'Sisyphean task'.

Building on this conceptualization, German sociologists of work have evaluated Germany's Hartz reforms ${ }^{\mathrm{i}}$ by examining the effects of strict conditionality on the work orientations and behaviour of claimants (Dörre et al 2013). Using semi-structured qualitative interviews with 99 claimants (in some cases with one or two follow-up interviews) and 95 institutional actors in four locales, they depict participants' work orientations, job-seeking activities, and interactions with jobcentre staff, as well as their transitions between jobs, activation schemes, and unemployment. They find little evidence of upward mobility through 
activation schemes and much evidence of circular mobility, in which precarity becomes a permanent state.

Welfare administrators play an important role in this process, Dörre et al argue, by reframing unemployment as a competition, through situations in which claimants are tested and have to prove that they are eligible and fulfilling their duties (e.g. through job applications, make-work schemes, and means tests). While some claimants accept these control practices, others see them as a bureaucratic apparatus of coercion that privileges some, devalues others, and stigmatizes anyone subject to them for an extended period of time. In popular German parlance, Hartz IV refers to a law reforming the benefits system; a means-tested benefit outside of the unemployment insurance system but (usually) subject to strict work requirements; and a group of five million individuals receiving this benefit.

While the principle behind the reforms is to stimulate job search activities Dörre et al (2013) observe numerous cases in which claimants work hard to escape precarity, but find their dealings with the welfare apparatus demotivating and exhausting. Here, activation policy reinforces the problem that it is supposed to solve. They also find numerous examples of people so motivated to escape from the benefits system that they sacrifice income by taking jobs paying below benefit levels. Rather than improved incentives for upward mobility through work, the authors observe considerable desperation to leave the benefits system, which gives employers an extra incentive to create low-paying jobs. ${ }^{2}$

For the German school, the public policies that reproduce the vulnerability of the precariat do not merely work through unleashing labour market competition (Brinkmann et al

\footnotetext{
${ }^{2}$ In January 2015 Germany introduced a statutory minimum wage of $€ 8.50$ that covered all industries. The effect of this rule remains to be seen, however, since long-term unemployed (i.e. those who have been jobless for at least 12 months) are not covered during the first 6 months of their employment.
} 
2006; Scherschel et al 2012; Dörre et al 2013). Activation involves detailed state intervention in individual transitions back and forth between work and non-work statuses. This directly affects people in the benefits system, but also has disciplinary effects in Germany's industrial 'core', since workers with permanent contracts of employment may face redundancy and insertion into the Hartz IV stratum. This 'zone of endangered integration' facing this threat of downward social mobility is estimated, based on nationally representative worker surveys, at one third of Germany's workforce (Brinkmann et al 2006: 57, 61-62).

\section{The dysfunctions of activation}

While the German-language literature provides rich insights into the effects of ALMPs, much English-language literature examines their effectiveness. One set of problems has to do with the labour process in welfare administration. While front-line workers need discretion and time to deal with the complex needs of their jobless clients, they face limited resources, monitoring, speedups and exhaustion (Brodkin 2007; Foster and Hoggett 1999). Marketization exacerbates these problems, since the coming and going of competitively tendered government contracts undermines relationships between staff and clients, and payment by results makes managers shift staff time towards clients who are easier to place in jobs (creaming-and-parking effects) (Bredgaard and Larsen 2008). Competition between providers, furthermore, undermines cooperative relationships required by certain complex services (Hipp and Warner 2008). These dysfunctions undermine the ability of staff to meet needs (due to poor coordination and pressures for 'parking'), while forcing them to put pressure on job-ready clients to take any job offer (due to monitoring of outcomes and financial pressures for 'creaming'). 
Employer responses to ALMPs are not straightforward. One problem is discrimination and scepticism among employers about the suitability of lone parents, people with disabilities, older unemployed people and younger unemployed people for job openings (Holzer and Stoll 2001) and the separation of ALMP participation from mainstream recruitment (Lee et al 1991). While ALMPs supposedly offer employers flexibility, the welfare state's 'handicapology' (Castel 2003) flags up complex problems and indicates workers who do not necessarily behave 'flexibly'. Punitive welfare reforms, furthermore, may create disincentives for employees in secure jobs to quit, thereby reducing the quality and quantity of job vacancies (Knuth 2012: 581-2).

Even when employers do recruit using ALMPs, it may not lead to increased labourmarket participation. Employers may employ workers on schemes rather than hiring staff (substitution effects), use the competitive advantage gained to expand market share and prevent job creation by competitor firms (displacement effects) or through ALMPs hire the same individuals whom they might have hired on the open labour market (deadweight effects). Programme evaluators have long been aware of these effects (OECD 1994; Mizen 2003: 91), and a German government review of evaluation evidence has found at least one of them in eight of the ten main activation 'instruments' (Koch et al 2011). ALMPs may thus reduce the quality of jobs without increasing their quantity.

The resistance of those being activated, whether through the individual avoidance of low-wage jobs (Lindsay and McQuaid 2004), collective activism (Reese 2011), or labourmarket exit, is a third issue. Since 2012 British claimant groups have resisted mandatory work-for-benefit schemes using social media, picketing of employers, and a high-profile lawsuit. Their victories include the public withdrawal of several large charities and highstreet retailers from these schemes (Boycott Workfare 2014). 
The difficulties of organizing welfare claimants are many. Unemployment is a transitory status, which makes 'unemployed activists' are less likely to form stable organizations than, for example, workers in quasi-permanent employment. Groups that sustain themselves may be 'becalmed' as activists become professional social workers with salaries paid by activation schemes (Royall 2009). Punitive welfare reforms can also corrode the solidarity between job holders and the unemployed by reinforcing negative stereotypes about the latter (Soss and Schram 2007). While the trade union interest in preventing recommodifying reforms is evident, any defence of social protection takes place against a backdrop of union decline (Waddington 2005) and unions sometimes view participation in ALMPs as an opportunity to influence policy or recruit members (Johnston et al 2013). Consequently, few examples exist of claimants forcing governments to reinstate lost welfare entitlements.

\section{Conclusion}

Again and again, the administrative machinery comes up against its own dysfunctions, the human material that it is supposed to transform, and weak employer demand. ALMPs would not succeed as a policy to increase employment even if they did succeed in ratcheting up labour market competition in the sense of the reserve army mechanism. The recommodification effect of workfarist ALMPs and the resulting wage restraint is itself dysfunctional, since it reinforces weak consumer demand, a cause of slow growth in capitalism (Vidal 2013; Stockhammer and Onaran 2013).

Studying ALMPs critically can enrich work and employment research in a few ways. Market discipline translates into workplace discipline through the well-known mechanism of insecurity, which affects both the precariat and workers in stable employment (Brinkmann et 
al 2006; Doogan 2009). ALMPs also engender state intervention in the workplace through job-placement schemes, employer engagement, and (with the UK's Universal Credit) conditions of in-work benefits. Workfarist ALMPs can be found in a variety of national 'regime types' (Eichhorst and Konle-Seidl 2008; Scherschel et al 2012), and it remains open what determines national variations in policy and their effects. Since internationalcomparative datasets do not capture many of the re-commodifying dimensions of ALMPs, such a comparative analysis would require considerable empirical work.

Finally, resistance by claimants and workers in this area is important and underresearched. Trade unions do find it difficult to work with claimants and organize the precariat, but the tightening of market discipline is also contrary to their core members' interests. Analyses of resistance success stories would be a welcome antidote to policy success stories.

\section{References}

Auer P (2010) What's in a name? The rise (and fall) of flexicurity. Journal of Industrial Relations 52(3): 371-386.

Blank R (2002) Evaluating welfare reform in the United States. Journal of Economic Literature 40(4): 1105-1166.

Boycott Workfare (2014) Pushing workfare closer to collapse. Available at: http://www.boycottworkfare.org/?p=4005.

Braverman H (1975) Labor and Monopoly Capital: The Degradation of work in the 20th Century. New York: Monthly Review Books.

Bredgaard T and Larsen F (2008) Quasi-markets in employment policy: do they deliver on promises? Social Policy and Society 7(03): 341-352.

Brinkmann U, Dörre K, Krämer, Röbenack S, and Speidel F (2006) Prekäre Arbeit. Ursachen, Ausmaß, soziale Fogen, und subjektive Verarbeitungsformen unsicherer Beschäftigungsverhältnisse. Bonn: FES. 
Brodkin E (2007) Bureaucracy Redux: Management Reformism and the Welfare State. Journal of Public Administration Research and Theory 17(1): 1-17.

Castel R (2003) From Manual Workers to Wage Laborers: The Transformation of the Social Question. London: Transaction.

Clasen J and Clegg D (2013) Regulating the risk of unemployment. Oxford: Oxford University Press.

Collinson D (1987) "Picking women": The recruitment of temporary workers in the mail order industry. Work, Employment and Society 1(3): 371-387.

Doogan, K (2009) New Capitalism: The Transformation of Work? Cambridge: Polity Press.

Dörre K, Scherschel K, Booth M, Marquardsen K, Haubner T, and Schierhorn K (2013) Bewaehungsproben fuer die Unterschicht? Frankfurt: Campus.

Eichhorst W and Konle-Seidl R (2008) Contingent Convergence: A comparative analysis of activation policies. Bonn: IZA.

Esping-Andersen G (1990) The Three Worlds of Welfare Capitalism. Cambridge: Polity Press.

Fevre R (2011) Still on the scrapheap? The meaning and characteristics of unemployment in prosperous welfare states. Work Employment and Society E-Special Issue.

Foster D and Hoggett P (1999) Change in the Benefits Agency: Empowering the Exhausted Worker? Work, Employment and Society 13(1): 19-39.

Furlong A (2006) Not a very NEET solution: representing problematic labour market transitions among early school-leavers. Work, Employment and Society 20(3): 553-569.

Gray A (2004) Unsocial Europe: Social protection or flexploitation? London: Pluto.

Green F (1991) The reserve army hypothesis: A survey of empirical applications. In: Dunne P (ed.) Quantitative Marxism. Cambridge: Polity.

Greenberg D, Ashworth K, Cebulla A, and Walker R (2005) When welfare-to-work programs seem to work well: Explaining why Riverside and Portland shine so brightly. Industrial and Labor Relations Review 59(1): 34-49.

Grover C (2005) New Labour, welfare reform, and the reserve army of labour. Capital and Class 27(17): 17-23.

Heyes J 2011. 'Flexicurity, employment protection and the jobs crisis', Work, Employment and Society, 25:4, 642-657 
Hipp L and Warner M (2008) Market Forces for the Unemployed? Training Vouchers in Germany and the USA. Social Policy \& Administration 42(1): 77-101.

Holzer H and Stoll M (2001) Employers and Welfare Recipients: The Effects of Welfare Reform in the Workplace. San Francisco: Public Policy Institute of California.

Jessop B (2002) The future of the capitalist state. London: Blackwell.

Johnston A, Kornelakis A, and Rodriguez d'Acri C (2012) Swords of justice in an age of retrenchment? The role of trade unions in welfare provision. Transfer. 18(2): 213-224.

Knuth M (2011) 'Widersprüchliche Dynamiken im deutschen Arbeitsmarkt', WSIMitteilungen, 64(11): 580-587.

Kretsos, L and Livanos I (2013) The Extent and Determinants of Precarious Employment in Europe. University of Greenwich: Unpublished manuscript.

Koch S, Spies C, Stephan G, Wolff J (2011) Kurz vor der Reform. Arbeitsmarktinstrumente auf dem Prüfstand. IAB Kurzbericht 11.

Lee, D., Marsden, D., Rickman, P., Duncombe, J. (1990) Scheming for youth. A study of YTS in the enterprise culture. Milton Keynes: Open University Press.

Levitas R (1998) The Inclusive Society. London: MacMillan.

Lindsay C and McQuaid R (2004) Avoiding the 'McJobs': Unemployed job seekers and attitudes to service work. Work, Employment, and Society 18(2): 297-319.

Marx K and Engels F (1973) Marx-Engels Werke, Band 23. Berlin: Dietz.

Mizen P (2003) The Changing State of Youth. Basingstoke: Palgrave

Nickell S (1997) Unemployment and labour market rigidities: Europe versus North America. Journal of Economic Perspectives 11(1): 55-74.

OECD (1994) The OECD Jobs Study. Facts, Analysis, Strategies. Paris: OECD.

Offe C (1984) The Contradictions of the Welfare State. London: Hutchinson.

Peck J (2001) Workfare States. London: Guildford.

Peck J (2002) Political Economies of Scale: Fast Policy, Interscalar Relations, and Neoliberal Workfare. Economic Geography 78(3): 331.

Pierson P (1994) Dismantling the Welfare State?: Reagan, Thatcher and the Politics of Retrenchment. Cambridge: Cambridge University Press.

Polanyi K (1957) The great transformation. Boston: Beacon Press. 
Pontusson J (2012) Once again a model: Nordic Social Democracy in a Globalized World. In: Cronin J, Ross G, and Schoch J (eds) What's left of the left. Democrats and Social Democrats in Challenging Times. Durham: Duke UP: 89-115.

Reese E (2011) They say cutback, we say fightback! Welfare activism in an era of retrenchment. New York: Russell Sage Foundation.

Royall F (2009) Political challengers, service providers or service recipients? In: Giugni M (ed) The Politics of Unemployment in Europe. Farnham: Ashgate: 117-132.

Rubery J (2011) Reconstruction amid deconstruction: or why we need more of the social in the European social models. Work, Employment, and Society 25(4): 658-674.

Scherschel K, Streckeisen P, Krenn M (eds) (2012) Neue Prekarität. Die Folgen aktivierender Arbeitsmarktpolitik - europäische Länder im Vergleich. Frankfurt: Campus.

Soss J and Schram S (2007) A Public Transformed? Welfare Reform as Policy Feedback. American Political Science Review 101(1): 111-127.

Standing G (2011) The precariat: The new dangerous class. London: Bloomsbury.

Stockhammer E and Onaran O (2013) Wage-led growth: theory, evidence, policy. Review of Keynesian Economics 1(1): 61-78.

Vidal M (2013) Postfordism as a dysfunctional accumulation regime: a comparative analysis of the USA, the UK and Germany. Work, Employment and Society 27(3): 451-471.

Waddington J (2005) Trade unions and the defence of the European social model. Industrial Relations Journal 36(6): 518-540.

Webb, S and Webb, B (eds.) (1909). The Break-up of the Poor Law. London: Longmans.

Weller S (2010) Financial stress and the long-term outcomes of job loss. Work, Employment and Society 26(1): 10-25.

Wiggan J (2014) Active labour market policy under the UK Conservative-Liberal Coalition Government: An Autonomist Marxist analysis. Working paper, University of Edinburgh

\footnotetext{
' The Hartz reforms were four 'Laws for Modern Labor Market Services', passed and implemented in 2003-5 under Schroeder's Red-Green government. While allowing new temporary and low-wage employment contracts, they overhauled welfare administration to promote activation, reduced workers' entitlements to insurance-based unemployment benefits, and introduced a means-tested unemployed benefit for those outside the insurance system.
} 